\title{
Do the Asian Drivers Undermine Export-oriented Industrialization in SSA?
}

\author{
RAPHAEL KAPLINSKY \\ Open University, Milton Keynes, UK
}

and

\author{
MIKE MORRIS * \\ University of Cape Town and University of KwaZulu Natal, South Africa
}

\begin{abstract}
Summary. - An increase in outward orientation in general, and in export-oriented manufacturing in particular is widely indicated as a suitable developmental path for SSA. The logic for this is drawn both from the demonstration effect of China and the earlier generation of Asian NICs, and from theory. However, the entry of China (and to a lesser extent India) into the global economy as a significant exporter of manufactures poses severe problems for export-oriented growth in SSA. This can be seen from SSA's recent experience in the clothing and textile sectors, often considered to be the first step in export-oriented manufacturing growth. Without sustained trade preferences over Asian producers, SSA's clothing and textile industry will be largely excluded from global markets and face significant threats in its domestic market. This has generalizable implications for other sectors, and for other sets of low income producers.

(c) 2007 Elsevier Ltd. All rights reserved.
\end{abstract}

Key words - export oriented industrialization, SSA, China, clothing and textile industry, fallacy of composition

\section{INTRODUCTION}

The development agenda continues to be dominated by the belief that the key to longterm growth lies in increasing integration into the global economy. The World Bank's influential assessment in 2002 of the link between poverty and deepening globalization forcefully promoted the case for further globalization, notably through rapid growth in developing country exports of manufactures (World Bank, 2002, p. xi). Heavily influenced by this multilateral- and bilateral-agency policy agenda, and drawing on the successful growth and manufactured export experience of the first generation of Asian NICs, SSA economies have increasingly oriented their long-term growth objectives around a graduation from the export of primary products to the export of manufactures. The demonstration effect of the astonishing emergence of China as a major global exporter of manufactures and its relatively successful performance in meeting the $\$ 1 /$ day Millennium Development Goal has provided further impetus to this policy consensus.

Two major sets of factors influence the effectiveness in SSA of this policy agenda of outward oriented growth based on the expansion of manufactured exports. The first comprises a cluster of endogenous factors which affect SSA's supply

\footnotetext{
* We are grateful to Masuma Farooki for assistance with the collection, compilation and analysis of much of the empirical data used in this paper, to Peter Minor and Jane O'Dell (Nathan Associates Inc.) for undertaking the survey of US buyers, to Jeff Readman and Leanne Sedowski for some of the interviews with SSA clothing manufacturers, to Jack Kipling for assistance on the SSA clothing industry, and for constructive comments from two anonymous reviewers and Sheila Page. Final revision accepted: June 4, 2007.
} 
response to global market opportunities. These include the quality of infrastructure, the effectiveness of property rights, peace and security, technological capabilities, and effective entrepreneurship. In all these respects, with the possible exception of South Africa, almost all SSA economies face formidable challenges. The second set of factors are those which are exogenous to SSA, reflecting changing dynamics in the global economy. The successful experience of Asia suggests that the last few decades have been a particularly opportune historical moment for emerging economies to pursue outward oriented strategies, especially in regard to the export of manufactures. This being the case, the policy challenge for SSA may be summarized as comprising the need to develop weak domestic capabilities and align these with favorable external market opportunities.

Mainstream economics provides a theoretical framework to justify outward orientation, particularly with regard to manufactured exports. Productivity growth arises in large part from the division of labor (Smith, 1776) and this is aided by access to large global markets, particularly in the context of technology-induced scale economies (Moores and Verdoorns' Laws; McCombie, 1986). Access to new and demanding external markets provides the incentive for innovation and technological change (Clerides, Lach, \& Tybout, 1998; Greenaway \& Kneller, 2007). Notwithstanding frictional adjustments, a dynamic global economy provides the scope for all participants, irrespective of absolute advantage, as long as they specialize in areas of comparative advantage (Ricardo, 1817). It is in these circumstances that we can observe the win-win alignment between endogenous and exogenous factors which drives the commitment to outward oriented industrial growth in much of SSA.

In this paper, we challenge the relevance of this manufactured-export oriented growth agenda for SSA. In summary, we argue that the intellectual rationale for the gains from trade hinges around the validity of Ricardo's invocation to specialize in areas of comparative advantage. We argue that Ricardo's framework depends crucially on his related assumptions of full employment and immobility of capital. In a world of structural excess capacity and capital mobility, it no longer follows that all countries will necessarily benefit from trade-openness (Kaplinsky, 2005). The global advance of the two Asian Driver economies of China and India-individually much larger than the Asian forerunners of Japan, Korea, Taiwan, Singapore, and Hong Kong, and collectively of even more formidable size - challenges both the small country assumption of trade theory and the assumption of full employment amongst global trading partners (Kaplinsky \& Messner, Introduction to this Special Issue). Given the absolute advantage of the Asian Driver (hereafter AD) economies in many sectors of relevance to potential SSA exporters, and given the mobility of global producers and buyers searching for least-cost supply, there is constrained space for some other (but of course not all other) participants in the contemporary global economy. SSA manufactured exports - existing and potential - are particularly adversely affected by the AD advance.

We evidence this view with an analysis of SSA's performance in the global garments and textile industries in Section 3, and consider the implications of these findings to other sectors and economies in Section 4. But, before undertaking this analysis, we briefly review SSA's recent trading experience in manufactures, both in relation to trade with the two major Asian Driver economies (China and India) and in sectors in which China and India participate effectively in the global economy (Section 2).

\section{SSA MANUFACTURED EXPORTS AND THE ASIAN DRIVERS}

\section{(a) Overall growth and trade performance}

There was a moderate revival in SSA's GDP, industrial, and manufacturing growth rates in the early years of the millennium (Table 1). Distinguishing between the first and second half of the period during 1990-2005 (when Structural Adjustment induced liberalization began to be implemented widely throughout SSA), the rate of growth of GDP and industrial value added quickened in the latter period. However, much of this industrial growth can be attributed to a replenishing of infrastructure and the processing of hard commodities since the growth of manufacturing value added (MVA) was lower than that of industrial value added, service sector value added, and agricultural value added. A second notable conclusion to be drawn from Table 1 is the relatively poor performance of SSA in comparison to that of China and India. With the exception of SSA's agricultural growth relative to that of India, SSA's performance lagged significantly behind that of both China 
Table 1. Average annual growth of GDP and sectoral value added: SSA, China, and India, 1990-97 and 1998-2005 (\%)

\begin{tabular}{|c|c|c|c|c|c|c|c|c|}
\hline & \multicolumn{4}{|c|}{ 1990-97 } & \multicolumn{4}{|c|}{ 1998-2005 } \\
\hline & World & SSA & China & India & World & SSA & China & India \\
\hline GDP growth & 2.75 & 1.92 & 10.56 & 5.48 & 2.93 & 3.70 & 8.90 & 6.42 \\
\hline Agricultural value added & 1.61 & 2.53 & 4.59 & 2.97 & 2.34 & 3.60 & 3.53 & 2.35 \\
\hline Industrial value added & 2.18 & 1.28 & 14.14 & 6.19 & 2.22 & 3.60 & 9.90 & 6.23 \\
\hline Manufacturing value added & - & 0.96 & 11.22 & 6.63 & 2.54 & 2.52 & NA & 6.05 \\
\hline Services value added & 2.96 & 1.99 & 9.53 & 7.21 & 2.87 & 3.72 & 9.60 & 8.30 \\
\hline
\end{tabular}

Source: Calculated from World Development Indicators (accessed through ESDS in January 2007).

Table 2. Share of MVA in GDP (at constant 1995 prices) $(\%)$

\begin{tabular}{llll}
\hline & 1995 & 2000 & $2004^{\mathrm{a}}$ \\
\hline Africa $^{\mathrm{b}}$ & 12.1 & 12.3 & 12.1 \\
China & 34.7 & 36.7 & 39 \\
India & 16.3 & 15.7 & 15.0 \\
Developing Group excl China & 19.2 & 20 & 20.4 \\
World & 19.8 & 20.1 & 19.9 \\
\hline
\end{tabular}

Source: UNIDO International Year Book 2006.

a Estimate.

${ }^{\mathrm{b}}$ For Africa and not SSA.

and India across the sectors. SSA performed better than the world average in the more recent period in all respects bar growth in MVA.

The share of manufacturing in SSA GDP was stable over the period during 1995-2005 (Table 2 ). This ratio is lower in absolute terms than in other developing countries in general and China in particular. Not surprisingly, SSA's share of global MVA remained minimal at less than $1 \%$ over the $1990-2005$ period. In contrast, that of China rose from $2.2 \%$ to $8 \%$ (and even more so, if calculated at PPP rates) in the same period (UNIDO International Year Book, 2006).

Changes in the policy regime in SSA favoring greater openness during the 1990s led to a notable increase in the trade/GDP ratio which grew from $52 \%$ in 1990 to $68 \%$ in 2005 . This compares with similar figures of $29-75 \%$ and 14 $40 \%$ for China and India, respectively (the end-date for India is 2004). Much of this growing trade openness was due to an expansion in merchandize trade; in 2005, SSA's merchandize trade/GDP ratio stood at $58 \%$, an increase from $41 \%$ in 1990 . Focusing on the export side of this trade/GDP structure, the rate of growth of SSA's merchandize exports in the most recent period (1998-2004) exceeded that of the global average (but not China or India, Table 3 ).

This impressive performance with regard to merchandize exports was largely due to the growth of SSA's oil and gas exports. The share
Table 3. Average annual growth rates of merchandize exports and imports (\%)

\begin{tabular}{lccccc}
\hline & \multicolumn{2}{c}{$1990-97$} & & \multicolumn{2}{c}{$1998-2004$} \\
\cline { 2 - 3 } \cline { 5 - 6 } \cline { 5 - 6 } & Exports & Imports & & Exports & Imports \\
\hline World & 8.1 & 7.7 & & 8.8 & 9.0 \\
SSA & 4.4 & 6.0 & & 12.5 & 8.1 \\
China & 17.1 & 15.8 & & 21.4 & 26.5 \\
India & 11.7 & 10.5 & & 13.8 & 14.5 \\
\hline
\end{tabular}

Source: Calculated from UNCTAD (accessed through www.unctad.org) in January 2007.

of oil and gas in SSA's total exports grew from $31 \%$ to $47 \%$ during $1995-2005$, while the share of manufacturing remained largely stable (Table 4). Oil and gas make the big difference to SSA's overall trade balance. With these commodities, the region had a rapidly growing trade surplus (rising from \$4.6bn in 1995 to $\$ 46.6$ bn in 2005); excluding oil and gas, SSA's trade deficit grew from $\$ 13 \mathrm{bn}$ to $\$ 20.9 \mathrm{bn}$ in the same period.

\section{(b) Structure of SSA's manufacturing trade}

In considering the structure of SSA's manufacturing exports, we utilize the Lall-criteria of technological intensity grouping products into five categories - primary commodities,

Table 4. SSA's exports the world (excluding China) $(\$ m)$

\begin{tabular}{lrrr}
\hline & 1995 & 2000 & \multicolumn{1}{c}{2005} \\
\hline $\begin{array}{l}\text { Oil/gas as \% of total } \\
\text { Manufactures as }\end{array}$ & 31 & 40 & 47 \\
$\quad$ \% of total & 20 & 22 & 21 \\
Trade balance (\$m) & & & \\
With oil/gas & 4,573 & 27,486 & 46,598 \\
Without oil/gas & $-13,109$ & $-4,695$ & $-20,926$ \\
\hline
\end{tabular}

Source: Calculated from COMTRADE (accessed through http://wits.worldbank.org) on March 23rd, 2007.

Data based on SSA as partner and not reporter. 
resource-based products, low-technology products, medium-technology products, and hightechnology products (Lall, 2000). Employing this taxonomy, Table 5 reflects the pattern of SSA's trade with the world, and compares this with India's and China's trade structure. In China's case, there was a significant shift up the technological profile over the decade, with the share of high-tech products in total exports reaching

Table 5. Technological intensity of exports: SSA, China, and India, 1990-2005 (\% of total)

\begin{tabular}{llll}
\hline \multicolumn{2}{c}{1995} & 2000 & 2005 \\
\hline \multicolumn{2}{l}{ China's export structure } & & \\
Primary & 10 & 7 & 4 \\
Resource-based & 11 & 9 & 8 \\
Low-tech & 46 & 41 & 32 \\
Medium-tech & 19 & 20 & 22 \\
High-tech & 13 & 22 & 33 \\
India's export structure & & & \\
Primary & 20 & 15 & 12 \\
Resource-based & 27 & 29 & 36 \\
Low-tech & 38 & 39 & 30 \\
Medium-tech & 11 & 12 & 16 \\
High-tech & 4.6 & 5.5 & 5.4 \\
SSA's export structure & & & \\
Primary & 61 & 65 & 68 \\
Resource-based & 22 & 19 & 16 \\
Low-tech & 6 & 5 & 4 \\
Medium-tech & 6 & 7 & 8 \\
High-tech & 1.1 & 1.0 & 0.8 \\
\hline
\end{tabular}

Source: Calculated from COMTRADE (accessed through http://wits.worldbank.org) on March 23rd, 2007.
$33 \%$ in the latter period. India saw a similar shift in profile, albeit at a slower rate of change and into the medium, rather than the high-tech reaches. By contrast, there was no shift in SSA into medium and high technology exports (overwhelmingly manufactures in the Lall classification), but rather a shift from resource-based processing industries into primary products (which are technology-intensive but with far fewer spillovers than in the case of manufactures). ${ }^{1}$

Excluding South Africa, which is a special case deserving of attention on its own, the sectoral composition of SSA's manufactured exports shows a heavy concentration on clothing and textiles. Table 6 sets out the data, beginning with "broad manufactures," that is, SITC Sectors 5, 6, 7, and 8 (minus SITC 68 non-ferrous metals). These more than doubled during 1990-2005, from $\$ 5.7 \mathrm{bn}$ to $\$ 12.5 \mathrm{bn}$. However, this impressive headline growth needs to be adjusted in some key respects. First, the largest component in 2005 was SITC 6672, unset diamonds, accounting for exports of $\$ 5.5 b n$. Second, there were significant "exports" of "railway/tramway" equipment (SITC 79 ) from Liberia (\$1.3bn in 2005, virtually entirely ships) and Senegal ( $£ 100 \mathrm{~m}$ in 2005 , virtually entirely aircraft). However, a closer look at the data show that both these economies were in trade deficit in both trade classifications. Their "exports" thus represent re-exports to the region. Third, included in this "broad manufactures" category" are also methanol exports from Equatorial Guinea (SITC 51211), which is effectively a petroleum export, and uranium

Table 6. "Broad" and "narrow" manufactures $(\$ m)$ and the share of clothing and textiles in SSA (excluding South Africa) exports (\%), 1990, 1995, 2000, and 2005

\begin{tabular}{lcccr}
\hline & 1990 & 1995 & 2000 & 2005 \\
\hline Value of production (\$m) & & & & \\
Broad manufactures & 5,674 & 6,039 & 6,838 & 12,453 \\
$\quad$ Narrow manufactures & 2,179 & 2,668 & 3,435 & 4,641 \\
$\quad$ (i.e., broad manufactures net & & & & \\
$\quad$ of diamonds, precious stones, & & & & \\
$\quad$ re-exports, oil and gas by-products, & & & & \\
$\quad$ and uranium) & 721 & 1,090 & 1,660 & 2,331 \\
Apparel & 198 & 222 & 168 & 121 \\
Textiles & 189 & 248 & 267 & 434 \\
Cork/wood manufactures & & & & \\
Share of narrow manufactures (\%) & 33.1 & 40.9 & 48.3 & 50.2 \\
Apparel & 9.1 & 8.3 & 4.9 & 2.6 \\
Textiles & 8.7 & 9.3 & 7.8 & 9.4 \\
Cork/wood manufactures & & & \\
\hline
\end{tabular}

Source: Calculated from COMTRADE accessed through http:/wits.worldbank.org on March 23rd, 2007. 
(SITC 52511) from Namibia and Niger. If we net out these items from the "broad manufactures category" we obtain a narrower classification of "narrow manufactures."

Table 6 shows that clothing and textiles accounted for a combined total of $53 \%$ of all "narrow manufactures" exports from SSA excluding South Africa in 2005, and that this had risen from $42 \%$ in 1990 . Within that, the share of low-tech and labor-intensive clothing rose from $33 \%$ to $50 \%$, and that of higher-tech and capital-intensive textiles fell from $9 \%$ to $2.6 \%$, reflecting the 3 rd country fabric provision of African Growth and Opportunities Act (AGOA). The next most significant "narrow manufactures" exports were corkwood manufactures $(9.4 \%$ ) (almost entirely veneer sheets, SITC 63412 and SITC 63451), followed by iron and steel products $(5.6 \%$, SITC 67$)$, and leather manufactures $(6.9 \%$, SITC 61$)$.

A final observation on the structure of nonSouth African manufactured exports concerns the low levels of value added in these expanded exports of clothing and textiles. Much of this occurs through the processing of imported fabrics and accessories (see below), mostly imported from China (and to a lesser extent from India) (Figure 1). Thus, although clothing exports increased significantly from $\$ 1.3 \mathrm{bn}$ to $\$ 2.5$ bn over the decade from 1995 , there was a larger proportionate increase in imports of textile and other clothing inputs from the ADs.

\section{(c) SSA trade with the Asian drivers}

Trade with the ADs comprised a small proportion of SSA's total trade in the early years of the millennium (Table 7). Despite very rapid growth, by 2005 , SSA exports to China and India were only $15.5 \%$ and $3.3 \%$ of trade with the developed economies. The ratios for imports were somewhat higher, albeit still less than 20\% of total imports from the developed economies. However, trade with the ADs has grown very rapidly, and at current and projected growth rates, this picture is likely to change very rapidly in the future. As Table 8 shows, although SSA trade with China is balanced in SSA's favor, this is entirely due to SSA's growing oil and gas exports. Without these, the trade balance has been both negative and growing. By contrast, SSA has a deficit in its trade with India, and at least until 2005 , this included a deficit with regard to petroleum products. The likelihood, however, is that SSA oil and gas exports to India will increase and a number of Indian oil and gas companies have been bidding to exploit reserves in SSA. ${ }^{2}$

The structure of SSA's trade with the ADs is somewhat different to that of trade with the rest of the world (Table 9). On the export side, trade

Table 7. SSA: trade with China and India as a proportion of trade with the industrialized countries (\% of total)

\begin{tabular}{lllll}
$\begin{array}{l}\text { As \% of trade } \\
\text { with developed } \\
\text { countries }\end{array}$ & 1990 & 1995 & 2000 & 2005 \\
China & & & & \\
Exports & 0.13 & 2.80 & 7.96 & 15.49 \\
Imports & 0.39 & 4.22 & 8.48 & 18.06 \\
India & & & & \\
Exports & 0.73 & 3.25 & 2.45 & 3.29 \\
Imports & 0.91 & 3.42 & 4.59 & 7.44 \\
\hline
\end{tabular}

Source: Calculated from COMTRADE (accessed through http://wits.worldbank.org) in January 2007.

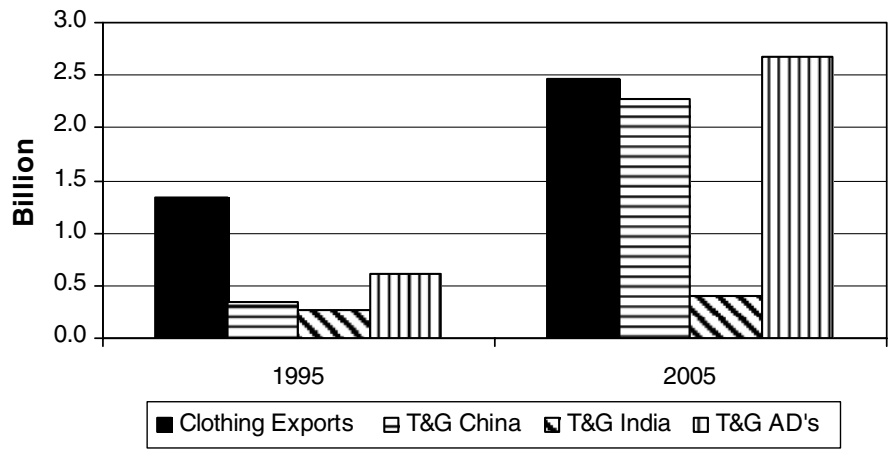

Figure 1. Value of total global SSA clothing exports and related inputs sourced from ADs. Source: Calculated from COMTRADE (accessed through http://wits.worldbank.org) on March $23^{\text {rd }} 2007$ Data based on SSA as partner and not reporter. 
Table 8. SSA's trade balance with China and India 1990-2005 (\$m)

\begin{tabular}{llccc}
\hline Total trade (value \$’000) & 1990 & 1995 & 2000 & 2005 \\
\hline China & & & & \\
Exports & 62,000 & $1,240,000$ & $5,341,000$ & $19,223,000$ \\
Imports & 134,000 & $1,770,000$ & $3,548,000$ & $13,291,000$ \\
Trade balance & $-72,000$ & $-529,000$ & $1,793,000$ & $5,932,000$ \\
Trade balance (without oil/gas) & $-69,000$ & $-724,000$ & $-1,741,000$ & $-7,261,000$ \\
India & & & & \\
Exports & 354,000 & $1,441,000$ & $1,647,000$ & $4,084,000$ \\
Imports & 310,000 & $1,434,000$ & $1,920,000$ & $5,478,000$ \\
Trade balance & 44,000 & 7,000 & $-273,000$ & $-1,394,000$ \\
Trade balance (without oil/Gas) & 44,000 & $-761,000$ & $-413,000$ & $-751,000$ \\
\hline
\end{tabular}

Source: Calculated from COMTRADE (accessed through http://wits.worldbank.org) in January 2007.

Table 9. Technological intensity of SSA's trade: share of exports and imports comprising different categories of products, $2005(\%)$

\begin{tabular}{|c|c|c|c|c|}
\hline & $\begin{array}{l}\text { World (excl. } \\
\text { China, India) }\end{array}$ & China & India & Intra-SSA \\
\hline \multicolumn{5}{|c|}{ Primary commodities } \\
\hline Exports & 67 & 81 & 38 & 17 \\
\hline Imports & 8 & 3 & 13 & 36 \\
\hline \multicolumn{5}{|c|}{ Resource-based } \\
\hline Exports & 16 & 15 & 46 & 35 \\
\hline Imports & 17 & 9 & 24 & 27 \\
\hline \multicolumn{5}{|c|}{ Low technology } \\
\hline Exports & 4 & 1 & 3 & 13 \\
\hline Imports & 10 & 40 & 22 & 11 \\
\hline \multicolumn{5}{|c|}{ Medium technology } \\
\hline Exports & 9 & 2 & 11 & 23 \\
\hline Imports & 46 & 33 & 28 & 20 \\
\hline \multicolumn{5}{|c|}{ High technology } \\
\hline Exports & 1 & 0.1 & 1.1 & 5 \\
\hline Imports & 18 & 16 & 12 & 4 \\
\hline
\end{tabular}

Source: Calculated from COMTRADE (accessed through http://wits.worldbank.org) in January 2007.

with China is disproportionately geared to primary commodities (oil, gas) and to India in resource-based products. In general, SSA's exports to China's are more similar to those of SSA's global exports than are its exports to India, to whom it disproportionately directs resource-based products. It is significant that intraregional exports are more technology intensive than those destined for non-SSA markets, and that the degree of technological intensity has been growing. On the import side, SSA sources medium and high technology products from China, and low and medium technology products from India. It is notable that SSA's exports are much more heavily concentrated than its imports. Taking China as an example, oil and gas alone account for $69.3 \%$ of the total, and the largest 10 product categories (HS 4-digit) for $81 \%$ of all exports. By contrast, on the import side, the 25 largest products only account for just over one-third of all of SSA's imports from China.

\section{MFA, QUOTA REMOVAL, AND SSA'S CLOTHING AND TEXTILES SECTOR}

In Section 2, we noted SSA's dismal performance with regard to manufactured exports. Outside of South Africa, these exports were significantly centered on clothing and textiles. Since the clothing and textile sector has historically been an important entry point for industrialization in low income economies, the impact of the ADs on SSA's advance in this sector holds important lessons for the wider impact of the ADs on SSA's industrial progress. Focusing on the trade vector, this impact may either be direct or indirect, but since the focus on this paper lies on the impact of the ADs on SSA's manufactured exports, it is to the indirect effect that our attention is directed. ${ }^{3}$

Three sets of factors have determined SSA's performance in the global market for clothing and textiles - the structure of the global industry itself (and particularly the importance of global buyers searching for scale and low-cost suppliers); the global regulation of trade; and SSA's relative competitiveness.

\section{(a) Structure of the global industry and the role of global buyers}

China is substantially the world's largest clothing exporter, increasing the value of its 
clothing exports by $667 \%$ from $\$ 9.7$ billion in 1990 to $\$ 74.2$ billion in 2005 . In 1990, China accounted for only $9 \%$ of the world's total clothing exports, but by 2005, its share had increased to $27 \%$, and if Hong Kong with $10 \%$ of the world total is included, China effectively accounted for more than one-third of world clothing exports. China is also the world's largest exporter of textiles products. Its textiles exports increased from $\$ 7.2$ billion in 1990 to $\$ 41.1$ billion in 2005 (469\%), while its share of the world total more than doubled (from 7\% in 1990 to $20 \%$ in 2005). Adding in Hong Kong gives China a share of $27 \%$ of global textile exports (Morris, Barnes, \& Esselaar, 2008, updated to include 2005 data).

SSA is only a small participant on this global stage. Its share of global textile exports was only $2.6 \%$ in 2004 , and $3.7 \%$ for clothing (WTO, 2005). Most of these clothing and textile exports are destined for the USA and here in the order of importance, the largest SSA clothing and textile exporters are Lesotho, Madagascar, Kenya, Mauritius, Swaziland, and South Africa (see below).

A key factor determining the structure of the global clothing and textiles sector is the concentration of global buying power in the industrialized countries (Gereffi \& Memedovic, 2003; Kaplinsky, 2005). The significance of this buyer concentration is the requirement of these buyers for large volumes (and of course low prices). This has made it difficult for small-scale suppliers to meet the requirements of large global buyers, and this has advantaged countries such as China with large volume plants, and transnational companies (often based in Hong Kong and Taiwan) who have a competitive advantage in organizing large scale production runs.

Global sourcing and production concentration has increasingly developed into a complex "triangular" division of labor in which the large oligopsonistic buyers and retailers in the major consuming markets determine their needs in close discussion with global sourcing firms (Gereffi, 1999). These global intermediaries then organize the production to meet these needs, predominantly by drawing on independent global and/or local producers. Increasingly, the intermediary system-integratorspredominantly based in East Asia - determine the geography of production (albeit not the geography of consumption) - in the global clothing and textiles sector (Gereffi, 1999; Gibbon, 2003; Gereffi \& Memedovic, 2003; Kaplinsky, 2005).
Given the constraints of the global trading structure (see below) sourcing decisions reflect costs and efficiency. Although the clothing industry has become increasingly characterized by the requirement for shorter lead-times, greater inter- and intra seasonal variety, and tighter logistics (Gereffi \& Memedovic, 2003; Kaplinsky, 2005; USITC, 2004), cost has been the king in this industry. The intensity of competition in these areas has been reflected in cost pressures, and as Figure 2 shows, since the mid1990s there has been a secular downtrend in the global price of clothing (as reflected in the unit price of clothing imports into the USA). These data are in current prices, so the fall in real prices was even greater over this period.

\section{(b) The regulation of global trade in clothing and textiles}

\section{(i) The evolving trade regime}

The most important determinant of global production structure has been the protective regime, since this has determined the pool of countries who can reliably serve these largescale global buyers with low cost and qualityassured product. Without going into too much detail, three protective regimes have been important, particularly in explaining SSA's role in this global industry. It is important to note here that it is the US protective regime which is most important to the SSA clothing and textiles industry, since the overwhelming share of exports is destined to the US market, particularly for Kenya, Lesotho, and Swaziland (Table $10)$.

Historically, the most important preferential trade regime has been the multifiber arrangement (MFA) (formally superseded by the Agreement on Textiles and Clothing in 1994, but still largely referred to as the MFA). This largely quota-based preferential trade agreement led to production spreading to an everincreasing number of countries. This was largely because firms in quota-full economies organized garment production in under-utilized quota producer countries (Gereffi, 1999). An increasing number of garment firms from Hong Kong, Korea, Taiwan, India, and Sri Lanka established plants in SSA to take advantage of MFA quotas, initially in Mauritius, and then in South Africa, Lesotho, Swaziland, Madagascar, and Kenya. Toward the end of the 1990s, Mauritian producers who had exceeded their quota sales into the EU (particularly) and the US relocated some of their production to Mad- 


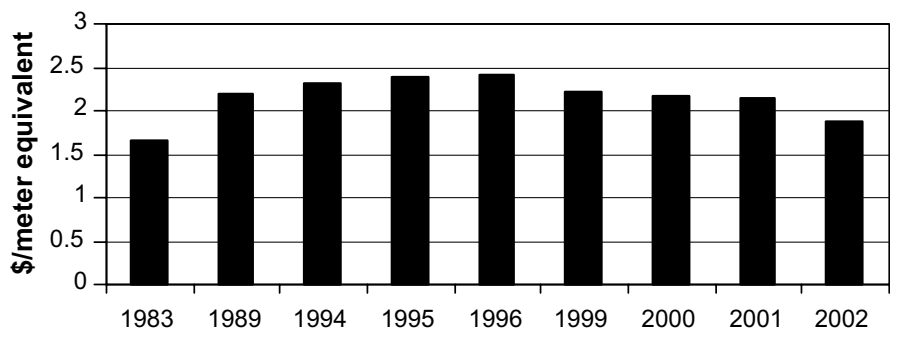

Figure 2. US import prices for clothing and textiles, 1983-2002 (\$/sq. m equivalent). Source: Manchester Trade Team (2005), from Textile Outlook International.

agascar to take advantage of its unutilized quotas. The MFA came to an end on December 31, 2004, and with it, the termination of all quotas on textiles and clothing trade between member states of the WTO. However, the removal of quotas did not mean a "level playing field" since global trade in clothing and textiles is still regulated by tariffs. In the case of the US, in 2005, the weighted average tariff (for world) for textiles was $6.93 \%$, while that for apparel was $11.36 \%$ (TRAINS data-based accessed through http://wits.worldbank.org on January 24th, 2007).

AGOA was introduced in May 2000 and aimed to facilitate SSA export-led growth by extending GSP tariff preferences to a wider range of products (subject to minimum levels of value added). The largest manufacturing sector beneficiary of AGOA has been the clothing and textiles sector, since clothing and textiles has been excluded from the GSP scheme. AGOA incorporated different rules of origin to the GSP. It built on procedures which had been established early in the 1990s in relation to the Caribbean Basin Initiative allowing for the use of US-origin inputs or regional inputs in the calculation of minimum levels of value added $(35 \%)$.

Nevertheless, despite these concessions, other than South Africa and Mauritius, few SSA economies were able to meet these rules of origin in the clothing and textiles sector. Thus, in a further key amendment, AGOA-qualifying countries, which were classified as being in the "least developed" category, were subject to a further amendment to GSP rules of origin. That is, until September 2007 (subsequently amended with modifications to September 2010 - see below) they could source their material and accessory inputs from non-AGOA and non-US bases suppliers (up to a restricted share of the US clothing imports), including from
China and other Asian economies. In other words, they were freed from the minimum value added requirement.

(ii) AGOA and SSA clothing and textile exports AGOA has had a critical impact on SSA's global (including intra-regional) clothing and textile exports. Three major trends can be discerned (Table 10). First, it led to a rapid expansion of trade. In three low income economiesKenya, Lesotho, and Swaziland-between 1999 and 2004, clothing exports grew from virtually nothing to $\$ 495 \mathrm{~m}$ for Lesotho, $\$ 333 \mathrm{~m}$ for Kenya, and \$205m for Swaziland. For Lesotho and Swaziland, this comprized the overwhelming bulk of merchandize exports. In two other economies-South Africa and Mauritiusclothing and textile exports grew rapidly until 2003 (to \$1bn and \$1.6bn, respectively), but as the rules of origin derogation did not apply to them, and (in the case of South Africa) the exchange rate rapidly appreciated, exports began to fell sharply after 2003. In the case of Madagascar, exports to the US largely followed the pattern of the industry's principals, many of whom had relocated to Madagascar from Mauritius. Second, the share of exports going to the US was similarly dominating for Kenya, Lesotho, and Swaziland, but less so for Madagascar, South Africa, and Mauritius. ${ }^{4}$ And, third, virtually all exports to the US were under the AGOA preferential scheme.

(iii) Impact of quota removal on SSA clothing and textile exports to the US

In assessing the outcome of the two years of quota removal on these six SSA clothing and textile exporters, we concentrate on the clothing sector since, with the exception of South Africa, there are negligible direct exports of textiles to the US. In each case we compare export volumes and market shares for all exports. 
Table 10. Global exports and share of US in exports of major SSA clothing and textile exporting economies

\begin{tabular}{|c|c|c|c|c|}
\hline Country & Year & Exports $\${ }^{\prime} 000$ & US Share $(\%)$ & $\begin{array}{l}\text { AGOA as share of } \\
\text { exports to US }(\%)\end{array}$ \\
\hline \multirow[t]{6}{*}{ Kenya } & 2000 & 78,000 & 89.6 & NA \\
\hline & 2001 & 87,000 & 92.7 & 80 \\
\hline & 2002 & 156,000 & 95.9 & 96.6 \\
\hline & 2003 & 234,000 & 95.8 & 93.7 \\
\hline & 2004 & 333,000 & 95.4 & 97.9 \\
\hline & 2005 & 306,000 & 95.3 & 98.5 \\
\hline \multirow[t]{6}{*}{ Lesotho } & 2000 & 154,000 & 94.9 & NA \\
\hline & 2001 & 237,000 & 94.3 & 60.1 \\
\hline & 2002 & 350,000 & 97.9 & 98.9 \\
\hline & 2003 & 429,000 & 97.7 & 94.9 \\
\hline & 2004 & 496,000 & 97.3 & 98.2 \\
\hline & 2005 & 406,000 & 96.5 & 99.4 \\
\hline \multirow[t]{6}{*}{ Madagascar } & 2000 & 633,000 & 18.9 & NA \\
\hline & 2001 & 709,000 & 27.4 & 51.8 \\
\hline & 2002 & 387,000 & 26.1 & 84.4 \\
\hline & 2003 & 527,000 & 41.5 & 94.8 \\
\hline & 2004 & 784,000 & 45.5 & 97.2 \\
\hline & 2005 & 771,000 & 37.0 & 98.5 \\
\hline \multirow[t]{6}{*}{ Mauritius } & 2000 & $1,652,000$ & 16.3 & NA \\
\hline & 2001 & $1,561,000$ & 16.6 & 16.3 \\
\hline & 2002 & $1,524,000$ & 18.3 & 41.8 \\
\hline & 2003 & $1,629,000$ & 17.9 & 50.2 \\
\hline & 2004 & $1,638,000$ & 15.0 & 65.2 \\
\hline & 2005 & $1,384,000$ & 12.4 & 85.8 \\
\hline \multirow{6}{*}{ South Africa } & 2000 & 867,000 & 31.0 & NA \\
\hline & 2001 & 864,000 & 38.3 & 17.4 \\
\hline & 2002 & 927,000 & 39.1 & 46.9 \\
\hline & 2003 & $1,027,000$ & 41.2 & 48.7 \\
\hline & 2004 & 756,000 & 44.1 & 66.3 \\
\hline & 2005 & 571,000 & 33.8 & 64.8 \\
\hline \multirow[t]{6}{*}{ Swaziland } & 2000 & 56,000 & 88.4 & NA \\
\hline & 2001 & 74,000 & 89.0 & 17.1 \\
\hline & 2002 & 118,000 & 92.9 & 82.7 \\
\hline & 2003 & 174,000 & 97.7 & 89.9 \\
\hline & 2004 & 205,000 & 98.3 & 98.3 \\
\hline & 2005 & 171,000 & 99.4 & 99.0 \\
\hline
\end{tabular}

Source: UNSD COMTRADE database, accessed via World Integrated Trade Solution (WITS) January 23rd, 2007; Country and sectoral data calculated on the basis of US imports; For share of AGOA, for 2001, Gibbon, 2003; for 2004-2006 values. www.agoa.info accessed on March 19th, 2007.

However, since a key to market developments lies in unit price behavior, we also analyze unit prices at the highest level of trade disaggregation (10-digit HS product categories).

As can be seen from Table 11 and Fig. 3, the major trends were that

- The value of SSA clothing exports to the US dropped by $26 \%$ during $2004-2006$. This masked differential country performance. Lesotho experienced a fall in export value of $15 \%$, most of which occurred in 2005 ; its exports stabilized in 2006. Madagascar, fared worse (a decline of $26 \%$ ), as did Swaziland $(24 \%)$. Kenya saw largely unchanged exports (a fall of only 5\%). The biggest casualties were South Africa (a decline of $53 \%$ ) and Mauritius (a decline of 48\%). Significantly neither of these latter two economies were able to utilize the 3rd country fabric derogation. 
Table 11. Change in value of clothing exports to the US, 2004, 2005, and 2006 (\%)

\begin{tabular}{|c|c|c|c|c|c|c|c|c|}
\hline & \multicolumn{2}{|c|}{$2005 / 2004$} & \multicolumn{2}{|c|}{$2006 / 2005$} & \multicolumn{2}{|c|}{ 2006/04 } & \multicolumn{2}{|c|}{$\begin{array}{l}\text { Change in unit } \\
\text { price of top } 10 \\
\text { products } 2005 / 04\end{array}$} \\
\hline & SSA & China & SSA & China & SSA & China & SSA & China \\
\hline AGOA & -16.5 & 56.9 & -11.2 & 17.8 & -25.9 & 84.8 & -0.9 & -46 \\
\hline Kenya & -2.5 & 79.4 & -2.7 & 18.7 & -5.1 & 112.9 & -1.9 & -45 \\
\hline Lesotho & -14.3 & 110.8 & -0.9 & 28.5 & -15.1 & 170.9 & -3.2 & -46 \\
\hline Madagascar & -14.4 & 72.2 & -13.9 & 21.0 & -26.3 & 108.3 & -9.5 & -44 \\
\hline Mauritius & -26.4 & 73.2 & -28.7 & 17.9 & -47.6 & 104.2 & -4.6 & -45 \\
\hline Swaziland & -9.9 & 93.3 & -16.0 & 22.1 & -24.3 & 136.1 & -2.7 & -52 \\
\hline South Africa & -43.7 & 63.9 & -17.0 & 15.4 & -53.3 & 89.1 & 3.0 & -33 \\
\hline
\end{tabular}

Source: Calculated from http://dataweb.usitc.gov data, accessed on January 10th, 2007.

Unit prices calculated for top 10 products in 2004 for each AGOA country's exports.

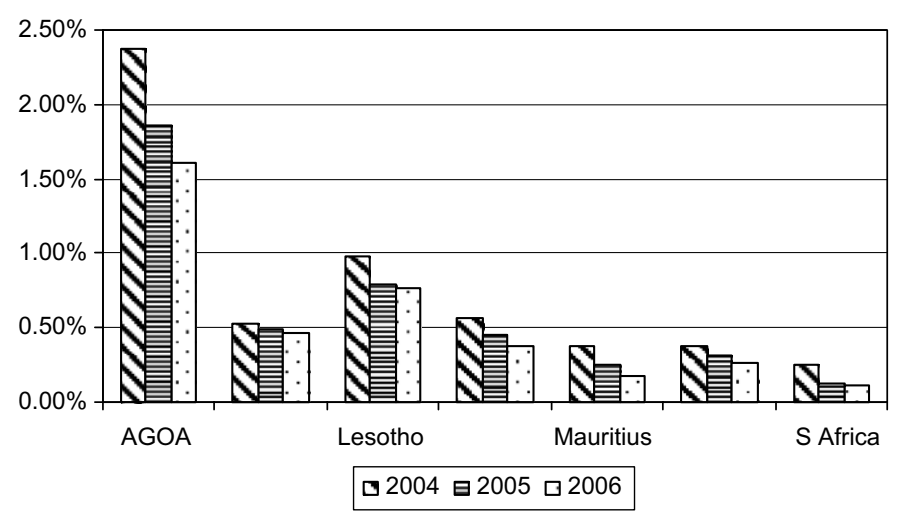

Figure 3. AGOA country share of US market in all product categories in which country exports were concentrated in 2004-06. Source: Calculated from http:/ldataweb.usitc.govdata, accessed on March 19th 2007.

- By contrast, in the same period, the value of China's clothing and textile exports to the US increased by $84 \%$. In the major products exported to the US by AGOA, the value of Chinese exports rose by $161 \%$.

- Unit prices on average remained reasonably stable in key product groupings for individual SSA countries in 2005, with Madagascar experiencing the sharpest decline $(10 \%){ }^{5}$ In contrast, in the same product groupings, the unit value of Chinese exports almost halved. (However, it is not clear to what extent this was due to a reduction in the unit prices of individual products, or China's entry into producing lower-end products within each of these 10-digit product classifications.)

- In general, AGOA economies performed less badly in their major exported items than they did in aggregate, suggesting a process of specialization. However, alarmingly, in general China's export growth and the rate of price decline in these AGOA-populated sectors were greater than for its overall textile and clothing exports, suggesting potentially heightened competition for SSA products in the future.

- There has been significant churn as exporting firms in SSA have struggled with competition. For example, eight of the 10 largest product items (10-digit classification) exported from AGOA during January and November 2006 were not exported to the US in the same period in 2005, and only seven of the 10 major exported items in 2005 were exported in 2006.

- The share of SSA exporters in the US clothing and textiles imports grew during 2001-04, reflecting the combination of quota-access and preferential AGOA 
trading arrangements. However, the removal of MFA quotas set back this advance, and African exporters experienced a significant fall in their share of the US market after quota removal (Fig. 3). By contrast, the share of China in each of these major product markets grew significantly.

A major consequence of this decline in exports from the AGOA region was the impact on employment and overall economic activity. At its peak, in 2002, Lesotho's clothing exports to the US accounted for virtually all manufactured exports, and were equivalent to $50 \%$ of GDP. In Kenya in 2003, clothing enterprises accounted for the equivalent of nearly $20 \%$ of all formal sector manufacturing employment. Table 12 shows the impact of quota removal on employment in 2005. In Swaziland, most severely affected, overall employment almost halved. In Lesotho, in the first half of 2005, eight of the 47 garment exporting factories closed and employment fell by $26 \%$. Even in Kenya (where clothing exports had only fallen by $2.5 \%$ in 2005 ), employment declined by nearly $10 \%$. The impact on South Africa is more severe than appears from Table 12, since there had been employment loss in the industry in the years preceding quota removal, although the exact figures are difficult to determine (Edwards \& Morris, 2006). This was a result of competition in third country markets (South Africa had never been able to benefit from the 3rd country fabric provision), an appreciation of the Rand, and the direct impact of Chinese competition in the domestic market.

However, after this initial decline following the removal of MFA quotas in 2005, the position in Lesotho and Kenya stabilized in 2006. In Lesotho's case, employment rose from the trough of 40,000 in mid-2005 to 45,000 in late 2006, still below the 2004 peak of 54,000 in 2004, and the decline in export value was

Table 12. Employment decline in the clothing sector, 2004-05

\begin{tabular}{lccc}
\hline & 2004 & 2005 & $\%$ decline \\
\hline Kenya & 34,614 & 31,745 & 9.3 \\
Lesotho & 54,000 & 40,000 & 25.9 \\
South Africa & 98,000 & 83,000 & 15.3 \\
Swaziland & 28,000 & 16,000 & 42.9 \\
\hline
\end{tabular}

Source: Kenya and Swaziland-Industry and Government interviews; Lesotho-Morris and Sedowski (2006b); South Africa-Edwards and Morris (2006). halted. In Kenya, the fall in export values remained low. Interviews with manufactures and buyers in both countries and the US suggest three factors which explain this stabilizing performance. First, in the case of Lesotho, its DCCS scheme ${ }^{6}$ provided subsidies to local producers. Second, the US buyers sourcing from Lesotho were mindful of the possibility of China Safeguards being sustained. ${ }^{7}$ Third, in both countries buyers and producers had the expectation that the 3rd country sourcing provision (which had been due to expire in September 2005) would be maintained (as we shall see below, this was broadly correct).

Why did the other AGOA exporters not experience a similar stabilization in 2006? Neither South Africa nor Mauritius was able to benefit from the 3rd country fabric provision. Moreover, South African producers experienced a rising exchange rate and suffered more than most from a breakdown in extending the DCCS. In the case of Swaziland, some of the loss of exports to the US was compensated for by finding new markets in South Africa. The stabilization of exports in 2006 is not reflected in the data because it is intra-SACU trade and appears as an increase in clothes for the domestic market. Moreover, Swaziland did not benefit from an efficient policy infrastructure which has distinguished Lesotho's response to the crisis. Finally, in the case of Madagascar, two factors led to a diversion of exports away from the USA and into other markets. Firstly, many of the principals in the clothing sector were of Mauritian or European origin, and they had made the strategic decision to focus on the EU market (witness the relatively low share of the US in Madagascar's exports in Table 10 above). ${ }^{8}$ Secondly, in 2005 the Malagasy producers began to supply the rapidly expanding South African market.

\section{(c) SSA's competitive gap}

In assessing the nature and determinants of SSA's lack of competitiveness in US markets, we polled the views of 20 US buyers in the summer of 2005 (see Kaplinsky \& Morris, 2006 for more detail). These companies are large, multistore operations with substantive global sourcing activities in clothing and other consumer goods. The participants came from four key market segments: branded specialty retail (nine responses), manufacturers (branded and private label, eight responses), department stores (two responses), and mass merchants (one 
response). The share of their total sourcing portfolio, which comes from SSA, ranges from $1 \%$ to $5 \%$ with the exception of one small company (turnover of $\$ 30 \mathrm{~m}$ in 2004) which obtained $30 \%$ of its product from SSA.

AGOA preferences were very important in the decision to source from SSA, with more than half of the buyers (10 out of 19) reporting that it was "very important" (Fig. 4). However, even more important was the view that it was the derogation on the rules of origin allowing AGOA economies to source fabrics from Asia which made it possible for these economies to compete ( 15 of the 19 buyers characterized this as being "very important"). Few of the buyers in this survey thought that existing or likely future "China safeguards" would be the marginal or decisive factor, although as we have seen in the case of Lesotho, this was an important consideration for some buyers. A majority of buyers also thought that consumer pressures on Corporate Social Responsibility (CSR) were a significant factor in sourcing from SSA, reflecting the growing commercial need of buyers to show awareness of the poverty-impact of their sourcing decisions.

We also asked the US buyers to rank the performance of firms in SSA when compared to Chinese and Indian counterparts (Fig. 5). Chinese firm capabilities were clearly seen to be more developed, in every respect, followed by Indian suppliers and then, some way behind, by SSA suppliers. The performance gap was smallest for labor relations, and greatest for delivery time and flexibility, product development capabilities, technology levels, and quality. With the exception of delivery time, these are all areas where SSA firms can improve and this is an issue which we address below.

Although, historically, quotas were important in the establishment of the export-oriented clothing and textiles sector in SSA, the key to understanding the future prospects of SSA AGOA exporters lies in the realm of costs. Within this, the degree of competitive advantage held by AGOA exporters arises from their duty preferences. And, here, US nominal tariffs significantly underestimate the degree of preference which AGOA producers are actually accorded. This can be seen by taking the example of two different products exported by Swaziland producers (Table 13). The first product is cotton denim jeans, where nominal duty preference was $16.6 \%$ in 2005 , and the second is synthetic women's underwear, where the nominal duty preference is higher, at $28.2 \%$.

In effect, these tariffs are a form of cost-subsidy to exporting firms. However, the rates of effective subsidy on these products are in fact much higher than these nominal rates, due to

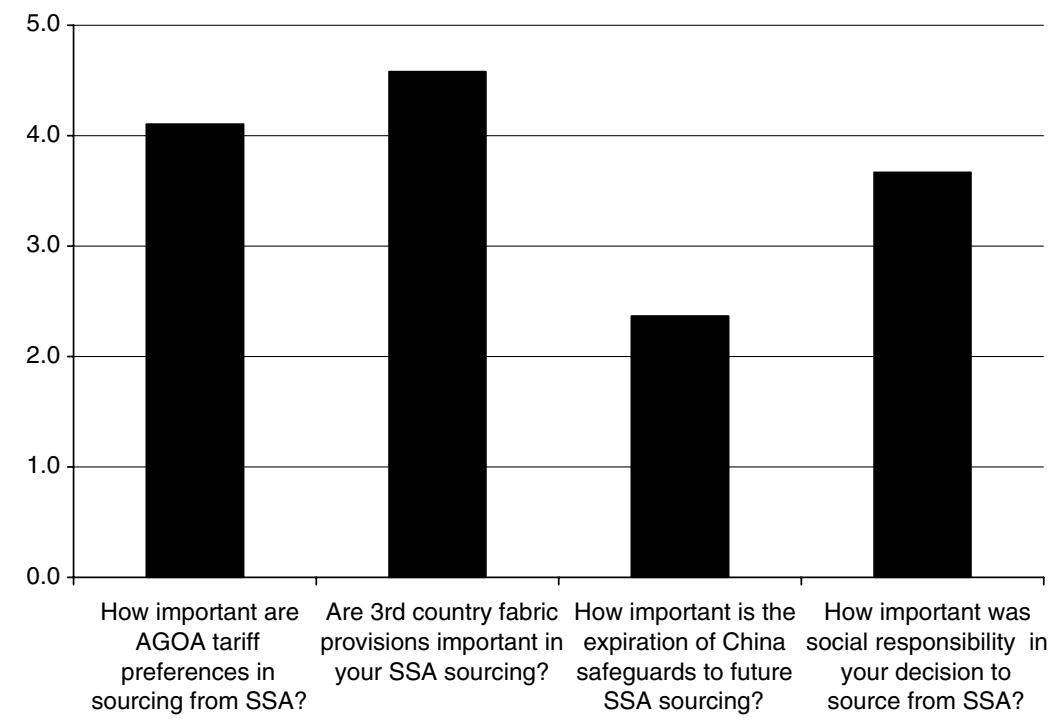

Figure 4. Buyer perceptions of the relative importance of AGOA preferences, China safeguards, and corporate social responsibility in the decision to source from SSA ( $1=$ not important; $5=$ very important $)$. Source: Interviews, mid2005. 


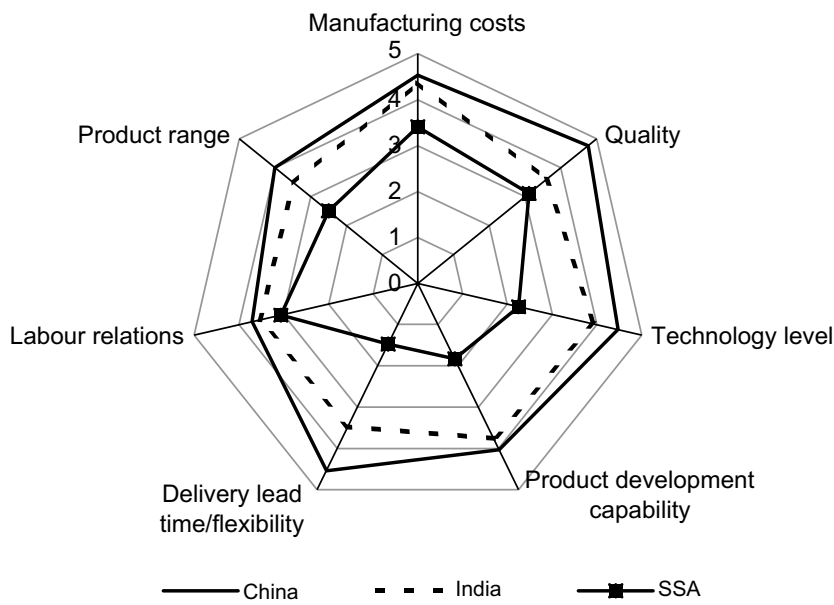

Figure 5. The performance of SSA, China, and India clothing firms on operational factors $(1=$ very poor performance; 5 = excellent performance). Source: Company interviews.

Table 13. Composition of value added and effective rates of subsidy in cotton denim jeans and synthetic women's undergarments in two Swaziland clothing factories (\%) (2005)

\begin{tabular}{llc}
\hline & $\begin{array}{c}\text { Denim } \\
\text { jeans }\end{array}$ & $\begin{array}{c}\text { Synthetic } \\
\text { women's } \\
\text { undergarments }\end{array}$ \\
\hline Labor costs & 45 & 30 \\
Fabric and other & 40 & 66 \\
$\quad$ imported inputs & 3 & 1 \\
Utilities & 2 & 2 \\
Distribution & 10 & 1 \\
Other (agent fee, & & \\
$\quad$ transport, etc.) & 100 & 100 \\
Total & 16.6 & 28.2 \\
Duty preference & 27.7 & 83.9 \\
Effective rate of subsidy & 27.7 \\
\hline
\end{tabular}

Source: Company interviews.

the derogation which Swaziland (and all other AGOA producers bar Mauritius and South Africa) producers have in using imported fabrics. That is, the nominal duty applies to the whole value of the product, but for AGOA producers using the fabrics derogation, much of the value of their output is made up of imported material. Moreover, not only do the synthetic products' manufacturers gain from higher duties, but also because in general cotton products are more complex to manufacture, the proportion of (generally imported) cotton fabric is in fact lower than in the case of imported synthetic material products.
Hence, in the case of cotton products (such as denim), the effective rate of subsidy provided by this protective regime is $27.7 \%$ (rather than $16.6 \%$ ), and in the case of synthetic products (such as underwear) it is $83.9 \%$ (rather than $28.2 \%)$.

Without the derogation from the AGOA rules of origin, which allow least developed qualifying SSA economies to import their fabrics from outside of the region (or the US), little of the clothing and textile industries in the region would survive. As can be seen from Fig. 6, excluding Mauritius and South Africa (who are unable to utilize fabrics imported from outside the region), almost all fabric in AGOA clothing exports has been imported (although the new denim mill opened in Lesotho in 2004 will reduce this somewhat in the future, particularly in the light of amended AGOA rules of origin-see below). (The lower figure for AGOA in this figure is that South African and Mauritian AGOA clothing exports to the US do not use imported fabrics.)

With the exception of South Africa, SSA wage costs are proximate to many Chinese plants. Here, those economies whose countries were linked to the Rand (South Africa, Lesotho, and Swaziland) experienced an increase in the dollar value of wages due to exchange rate appreciation after 2001. But wages are only one component of unit labor costs. A detailed investigation of productivity in Lesotho observed low levels of skill and efficiency (Salm, Grant, Green, Haycock, \& Raimondo, 2002). 


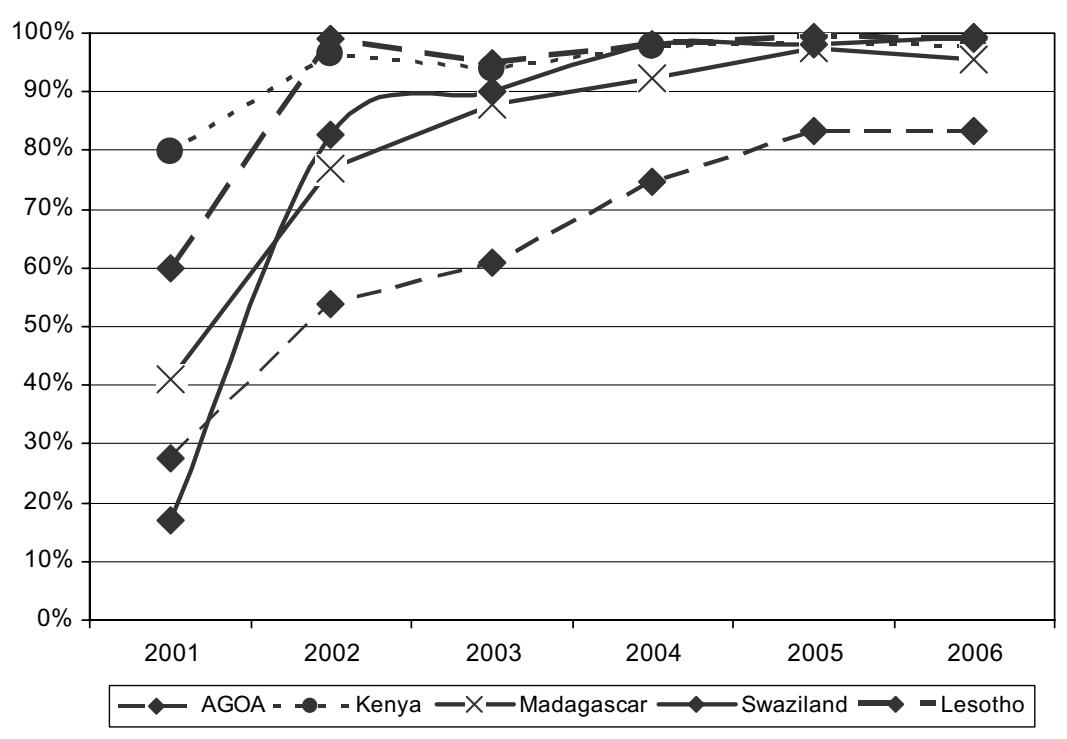

Figure 6. Share of foreign fabric in AGOA exports to US, 2001-06.

Middle management was particularly weak, and was largely made up of Chinese workers with shopfloor experience, but little management know-how and largely unable to communicate with the Sesotho speaking labor force. ${ }^{9}$

The Manchester Trade Team (2005) compared costs along a range of factors for COMESA and China and India for an equivalent product to show the non-labor-cost barriers faced by SSA clothing exporters. They found that

- Export finance costs in Kenya (13\% p.a.) and Madagascar (18\% p.a) were much higher than in China $(5.5 \%)$ and India $(10.5 \%)$.

- Material costs were much higher in Kenya (\$3/sq. ft) and Madagascar (\$4/sq. ft) than in China (\$1.50/sq. ft) and in India (\$2.50/ sq. ft).

- Transport costs to the US East Coast were lower for Kenya and Madagascar than for China ( $\$ 0.29$ versus $\$ 0.33$ per jean) but were lowest for India (\$0.23 per jean).

- The cost of machinery and of power were rather similar, but labor productivity with equivalent machines was significantly higher in China ( 25 pieces/day) than in India (21 p.d.), Kenya (18 p.d) and Madagascar (16 p.d).

Moreover, clothing manufactures depend heavily on access to reliable infrastructure. Here SSA producers are disadvantaged com- pared to their Asian counterparts. ${ }^{10}$ In some countries, water supplies critical to successful production are intermittent. One of the clothing firms in Lesotho had to close 13 out of 23 lines in 2004 due to water cost, availability, and quality and another Lesotho firm also observed poor water supplies as a handicap to production, along with power outages. Swazi firms also reported water shortages and power outages. In Kenya, production is often confined to EPZs precisely because of the failure of infrastructure supplies in the wider economy, and electricity costs are more than three times those in South Africa (Ikiara \& Ndirangu, 2003). Similarly, infrastructure problems act as a severe break on competitiveness in Madagascar (Morris \& Sedowski, 2006a). The comparison with China is stark, with Kenyan firms facing frequent outages, losing significant production due to power shortages, despite having to invest in generators, and new businesses have to wait very long periods for connection to the grid (World Bank, 2003).

The weakness of the transport system associated with bureaucratic hold-ups also leads to considerable delays and makes it almost impossible for SSA producers to produce items for higher-margin rapid-response markets. Unlike Asian competitors, SSA producers have to wait around 30 days to obtain their imported inputs and a further 28-40 days to deliver product to final markets (interviews with companies). 
Finally, those economies linked to the South African Rand faced a further disadvantage, both in terms of the level and volatility of this currency. Taking 2000 as the base year, during 2001-03 the Rand-\$ index rose and then fell from 100 , to 123 , to 149 and back to 107 . By contrast, the Chinese remnimbi was pegged at a steady rate to the US\$ (until mid-2005 when there was a mild revaluation of $3.5 \%$ ), as was the Kenyan shilling. Madagascar's currency was highly volatile, in part as a result of political unrest, and this posed a major problem for exporters. For example, in the first half of 2004, the Malagasy franc malgache lost nearly half its value against the dollar and the euro; then appreciated again by roughly $20 \%$ by the end of the year, a value which was sustained through 2005. Although this depreciation favored a resurrection of exports, the volatility had a deleterious inflationary impact on food and energy costs (Morris \& Sedowski, 2006a).

\section{(d) Future of AGOA clothing and textile exports}

How might SSA clothing and textile exporters fare in the future? Both the macroevidence on past performance and the interviews with buyers and manufactures suggest two determinants of future performance. The first of these is the trade regime, and the second is improvements in cost competitiveness, quality, and delivery.

With regard to the trade regime, after substantial lobbying by the African Cotton and Textiles Industry Forum (ACTIF), which represents SSA clothing exporters, important changes were made to the rules of origin in 2006. These contain significant positive changes, but also have potentially adverse implications for SSA's clothing exporters, but possibly also positive implications for its textile industry. The access to third country fabric was initially supposed to have expired in September 2007. But so severe was the impact of China on the AGOA exporters that the derogation was extended to 2012 and the intention of halving the value of the cap on these inputs has been abandoned. However, a new "abundant supply position" was introduced. That is, if the US determines that there is abundant supply in SSA in a particular fabric product, then it can be excluded from third country provision. For example, when Nientzing (Taiwanese firm) invested in a large denim plant in Lesotho in 2004 , it did so on the basis of the guarantee that after 2007 it would no longer be discriminated against by the AGOA rules of origin derogation. Hence, the 2006 AGOA extension included the declaration that denim was in an "abundant supply position" up to 30 million sq. m. Only once this capacity has been used in denim product exports from all of AGOA can producers gain access to the third country access.

Secondly, there is scope for productivity improvement and for effective industrial policy. Indeed there is some evidence that these improvements are beginning to occur-export values and volumes have held up much better than employment in Kenya, Lesotho, and Swaziland. Moreover, as various industry analysts have pointed out, there is considerable scope for further improvements in efficiency (Manchester Trade Team, 2005; Salm et al., 2002). But to achieve this requires tailored and effective government support and, more importantly, comprehensive firm-level restructuring in the industry. Enhanced capacities of innovation management - the ability to scan the environment, to develop appropriate strategies, and then to implement these strategies - are key to a successful response.

The Lesotho government has thus far been the most innovative, energetic, and successful in applying effective industrial support among the SSA countries. This includes creating the Lesotho National Development Corporation to manage and facilitate the industrial estates, an Inter-ministerial Task Team to eliminate bureaucratic blockages, tax incentives, specialized training programmes, government lobbying potential buyers, actively lobbying South Africa to fight for the extension of the Duty Credit Certificate Scheme for exporters, and setting up a Trade and Investment Facilitation Center to act as a "one-stop shop" (Morris \& Sedowski, 2006b). Madagascar, by contrast, has prioritized rural poverty and not industrial development, and hence has no effective industrial policy; nor has it expressed the intention of developing and implementing one (Morris \& Sedowski, 2006a).

Here, the response of two South African producers may provide some pointers to other SSA clothing manufacturers. A producer of underwear faced a $50 \%$ increase in imports in the first six months of 2005, predominantly from China, with a halving of its exports. It reacted with a rapid-response capability to help its retailers to slim overall inventories and to respond flexibly to changing market tastes. This strategy currently goes hand in hand with attempts (dri- 
ven by the domestic retailers) to synergize the local value chain and achieve systemic efficiency. A second option is to upgrade into specialized niches. One large firm began manufacturing suit linings in the 1960s, moving into industrial fabrics in the early 1970s. The industrial fabric division was developed to also cover the parachute sector, and specialized and high-tech industrial products now comprise $70 \%$ of output, and are targeted to reach $90 \%$ of sales by 2007. Significantly, this high-tech textile producer is very capital intensive in nature-labor costs are only $14 \%$ of costs (compared to $45 \%$ in the natural fibers clothing sector). Although this transition is beyond the reach of producers in other least developed SSA markets, the strategy of focusing on long-term upgrading and diversification provides an important lesson for SSA textile and clothing producers.

\section{FROM CLOTHING AND TEXTILES TO INDUSTRY: WHAT IMPACT WILL THE ASIAN DRIVERS HAVE ON SSA INDUSTRIALIZATION?}

To summarize the argument so far, in an attempt to promote growth, most SSA economies have moved to open their economies, with the medium- and long-term ambition of expanding manufacturing exports. This occurs in the context of relatively low levels of growth of manufacturing value added, a low and static share of manufacturing in GDP, and a degradation in the technological profile of exports. Performance with regard to manufactured exports has been poor, with the solitary exception of clothing exports by a limited number of economies. If South Africa is excluded, just over one half of all SSA manufactured exports comprise clothing, most of which is destined for the US under the AGOA scheme. This share has in fact risen from 33\% since 1990 .

The post-2005 removal of MFA quotas on Asian producers severely dented the rapid growth of SSA clothing and textile exports to the US. In the first two years of non-quota trade, SSA's clothing and textile exports fell by $26 \%$. In the first year of quota removal, employment in the clothing sector fell by $43 \%$ in Swaziland and by $26 \%$ in Lesotho. Following this quota-removal shock in 2005, once those firms that were only there for quota advantage had departed, the rate of decline was arrested in 2006 , at least for those countries having contin- ued access to the 3rd country fabric provision. Furthermore Madagascar, in particular, diverted exports from the US to the EU which also provides trade preferences to SSA producers (Morris \& Sedowski, 2006a). Nevertheless, a significant number of companies remained and continued to export. The common thread among these survivors is that whether they were oriented to the US or the EU market, they continued to operate in a preferential environment which offers them low tariffs and (in the case of the US) access to 3rd country fabrics. Competition from the Asian drivers also had harmful effects on firms producing for domestic markets. In January 2007, a Zambian textile mill built with Chinese aid in the 1970s - the largest in the country with an annual capacity of $17 \mathrm{~m}$ meters of fabric and 100,000 pieces of clothing - closed down in the face of cheap clothing imports from China. This led to the displacement of more than 1000 workers (McGreal, 2007). In South Africa, trades unions in the clothing and textile sectors were able to create enough political heat to force the imposition of quotas on clothing imports from China in 2006. The fact that these imports from the ADs have a generalized impact in reducing prices for consumers and thus have an important positive impact on consumer welfare carries less political weight than the adverse specific impact on an organized and vocal set of producers (both owners and workers).

To what extent is this experience related to the impact of the Asian Drivers on SSA's clothing and textile sector? The blunt reality is that SSA clothing and textile exporters cannot compete with Asian producers in general, and Chinese exporters in particular. They are unable to cope with a level playing-field.

Bearing in mind the major role played by clothing in SSA's manufactured exports, to what extent are these conclusions generalizable across manufacturing sectors? Here, we have only fragmentary evidence relating to two other consumer goods sectors, furniture, and footwear. As seen in Section 2, the second most significant manufactured export in SSA (excluding South Africa) is that of wood-based products, predominantly from West Africa. Our own preliminary research in this sector suggests that China and other newly dynamic Asian Driver economies are severely threatening the growth of competences in the value adding wood products sectors by undermining exports and the learning derived from exporting. For example, in 2005, Europe's major importer of garden 
furniture ceased sourcing from SSA (South Africa and Ghana), and divested itself of its joint venture equity in Ghana's major furniture exporting firm. Imports were switched to Vietnam and China. There is a single reason for this-SSA is not price competitive. In 2005, the same garden furniture product imported from South Africa at $£ 60$ could be obtained for $£ 50$ from Ghana, $£ 38$ from Vietnam, and only $£ 30$ from China (interviews). By contrast, China's furniture industry has been booming. During 1993-2002 it has moved from being the world's eighth largest to the second largest exporter. In the face of this inability to compete with Asia in general and China in particular, SSA's furniture manufacturers are moving backwards into their resource sectors, exporting raw logs, chips for the paper industry, and sawn timber (Kaplinsky \& Morris, 2006). There is also probably a significant trade in illegallylogged hardwoods from West and Central Africa to Asia, but this is by its nature very difficult to evidence. Much of this SSA-sourced timber is used by Asian manufacturers to produce furniture which displaces SSA from global furniture markets. ${ }^{11}$

And although SSA exports few shoes, Ethiopian manufacturers targeting the domestic market have been significantly eroded by imports sourced from China. Although these imports have stimulated an upgrading of processes and design by many domestic firms, they simultaneously had a negative impact on employment and domestic output. A study of 96 micro-, small, and medium domestic producers reported that as a consequence of Chinese competition, $28 \%$ were forced into bankruptcy, and $32 \%$ downsized activity. The average size of microenterprises fell from 7 to 4.8 employees, and of SMEs, from 41 to 17 (Egziabher, 2006).

Six wider conclusions can thus be drawn from the experience of SSA's clothing sector in the face of rising global competition from the ADs. First, the indirect impacts are significant and often dwarf the direct bilateral impact of the ADs on low income economies. For example, Lesotho, Swaziland, and Kenya have a limited number of bilateral trade links with China; yet they are very heavily affected by Chinese competition in third markets. Second, the damage to SSA industrialization is not just a problem for the present - it also affects future growth trajectories. Industries such as clothing, furniture, and shoes have proved to be important stepping stones for industrial development in other countries, including in the AD econo- mies themselves. If these sectors are significant disadvantaged by competition from the ADs, what path is to be followed if industrial development and economic diversification are to be pursued in the future?

Third, we have charted the impact of AD competition in SSA, and predominantly excluded South Africa from the analysis. To what extent are these conclusions relevant for South Africa, and for other regions in the world? There are compelling reasons to believe that the prospects facing large parts of Latin American and Caribbean industry are not dissimilar to those confronting SSA (Kaplinsky, 2005; Jenkins \& Dusserl Peters, 2006). Lall and Albaladejo showed that at least until the early years of the millennium, China was synergistically integrated into its local economy (Lall \& Albaladejo, 2004; see also McDonald, Robinson, \& Thierfelder, this volume). China in reality was the assembling tip of a series of East Asian regional value chains. But they warned that this complementary relationship between China and its neighbors might not be sustained in the future as Chinese industrial capabilities grow.

Fourth, our analysis challenges the pervasive commitment by the development community to an open-playing field in global trade, as well as the widespread belief that developing countries have a common interest in trade negotiations. The last thing SSA's outward oriented clothing industry needs is a level-playing-field free-trade environment. This would spell the death not just of its outward-oriented industry, but almost certainly also its domestically-oriented industry. SSA needs protection, but more against other low-income country producers than those from high income countries, which generally no longer compete with African exports.

Fifth, we have moved beyond a world in which "soft commodities" such as tea, coffee, and cocoa are homogeneous products with low barriers to entry, and manufactures are heterogeneous with high barriers to entry. In many sectors of manufacturing, especially of clothing, footwear, and other basic consumer goods, global manufacturing capabilities are widespread and barriers to entry are low. Yet, in the same sectors there are segments which are innovation intensive. Similarly, in many agricultural commodities there are also a range of innovationintensive niches. The same is true of the services sector which is increasingly diverse in nature. Hence, the generic challenge is not so much to favor the manufacturing/industrial/agricultural or service sectors as developing the capacity to 
produce rent-intensive products with rentintensive processes in all of these sectors (Kaplinsky, 2007). Importantly, these capabilities need to be sustained over time, they need to become dynamic capabilities (Teece, Pisano, \& Shuen, 1992) and to be supported by policies promoting innovation (Lall \& Teubal, 1998), innovation management (Tidd, Bessant, \& Pavitt, 2005), enhanced infrastructure and other supply-sided measures (Broadman, 2007), an appropriate National System of Innovation (Nelson, 1993) and, where appropriate, regional clusters promoting collective efficiency (Morris \& Barnes, 2007; Schmitz, 1998).
Finally to return to the theme which we addressed at the outset of this paper, based on the successful experience of first and second tier Asian producers (of whom China and India are the most recent examples), it is widely believed that export-oriented industrialization holds enormous potential for SSA and other low income economies. Based on the impact of the ADs on the global economy, our analysis challenges this belief, unless it is pursued in a severely restricted trade environment, an environment which runs counter to the drive by the WTO and other agencies to promote a freer-trading global economy.

\section{NOTES}

1. The Lall criteria treats oil and gas as a primary product (Lall, 2000).

2. For example, in 2006 India's Oil and Natural Gas Commission began exploring for oil in the Ivory Coast and then extended this to drilling. The Indian Ambassador to the Ivory Coast announced that India anticipated investing more than $\$ 1$ bn in the Ivory Coast over the 2006-10 period in oil, gas, and other primary sectors (http://newsvote.bbc.co.uk/2/hi/business/4791381.stm, Accessed 26.12.2007).

3. This discussion on vectors and direct and indirect impacts draws on the introductory article in this Special Issue.

4. Mauritius, Madagascar, and South Africa are differentiated from other AGOA-stimulated SSA clothing industries in that they have had historical links to the EU market. Mauritius has always exported the majority of its clothing output to the EU. Madagascar followed its principal in the post-MFA period by significantly switching exports to the EU. SSA producers benefit from significant tariff preferences - exceeding 12\%-over Chinese producers. However, the rules of origin into the EU are more restrictive than for entry into the US (twostage over one-stage conversion).

5. Because of the degree in churn in exported products (see below) it was not feasible to compare unit price performance over the 2006-04 period.

6. The Duty Credit Certificate Scheme subsidized clothing exporters from South African Customs Union member states but is regarded as being WTO noncompliant and was ended in 2005. However, under pressure from industry and governments of Lesotho, Swaziland, Botswana, and Namibia, the South African government belatedly, and lately, agreed to an interim extension until March 2007 with the proviso that industry would respond with a WTO compliant scheme.

7. The Chinese accession agreement to the WTO allows for safeguard tariffs and quotas to be applied solely against Chinese textiles and clothing, even when imports exert only a slight adverse impact on the domestic industry. In June 2005, the EU and China reached an agreement that limited 10 categories of Chinese textiles exports to the EU to between $8 \%$ and $12.5 \%$ growth above a specified base period for the next three years. In December 2005, the US and Chinese trade representatives agreed to a three-year agreement reducing US imports of Chinese textile and apparel products in all or parts of 34 sensitive categories.

8. Unlike China, which faces duties in exporting clothing into the EU (generally in excess of $12 \%$, but varying with the product), SSA exporters into the EU benefit from zero-tariff entry.

9. Although Salm's study is now dated, concerns about low productivity were corroborated by anecdotal evidence from management interviews in Morris and Sedowski (2006b).

10. In addition to the cited texts, this section is based on our interviews with producers in Kenya, Lesotho, South Africa, and Swaziland in late 2004.

11. This echoes the experience of Thailand, whose furniture industry suffered from Chinese competition in 
the Japanese market. Having developed this market for a new type of wood (historically rubber-wood had not been used for furniture), Thai producers found their market eroded by rubber-wood exports from China, using a combination of Thai and Indonesian rubber wood imports (Mitsuhashi, 2006).

\section{REFERENCES}

Broadman, H. (2007). Africa's silk road: China and India's new economic frontier. Washington DC: The World Bank.

Clerides, S., Lach, S., \& Tybout, J. (1998). Is 'Learningby-Exporting' important? Micro-Dynamic evidence from Colombia, Mexico, and Morocco. Quarterly Journal of Economics, 454(3), 903-947.

Edwards, L., \& Morris, M. (2006). Undressing the numbers: The employment effect of import quotas on clothing and textiles. Journal of Development Perspectives, 2(2).

Egziabher, T. G. (2006). Asian imports and coping strategies of medium, small and micro firms: The case of footwear sector in Ethiopia, mimeo, Addis Ababa. Addis Ababa: Addis Ababa University.

Gereffi, G. (1999). International trade and industrial upgrading in the apparel commodity chain. Journal of International Economics, 48(1), 37-70.

Gereffi, G., \& Memedovic, O. (2003). The global apparel value chain: What prospects for upgrading by developing countries? Sectoral Studies Series. Vienna: UNIDO.

Gibbon, P. (2003). The African growth and opportunity act and the global commodity chain for clothing. World Development, 31(11).

Greenaway, D., \& Kneller, R. (2007). Firm heterogeneity, exporting and foreign direct investment. Economic Journal, 117(517), F134-F161.

Ikiara, M. M., \& Ndirangu, L. K. (2003). Prospects of Kenya's clothing exports under AGOA after 2004, Discussion Paper 24, Nairobi: Kenya Institute for Public Policy Research and Analysis.

Jenkins, R. O., \& Peters, E. D. (2006). The impact of China on Latin America. Agenda-setting paper prepared for DFID, Brighton: Institute of Development Studies.

Kaplinsky, R. (2005). Globalization poverty and inequality: Between a rock and $a$ hard place. Cambridge: Policy Press.

Kaplinsky, R. \& Morris, M. (2006). Dangling by a thread: Can SSA survive the Chinese scissors? Report prepared for DFID, Brighton: Institute of Development Studies.

Kaplinsky, R. (2007). The impact of the Asian drivers on innovation and development strategies: Lesson from sub-Saharan Africa experience. International Journal of Technological Learning, Innovation and Development, 1(1), 65-82.

Lall, S. (2000). The technological structure and performance of developing country manufactured exports, 1995-1998. Oxford Development Studies, 28(3), 337-369.

Lall, S., \& Albaladejo, M. (2004). China's competitive performance: A threat to east Asian manufactured exports? World Development, 32(9), 1441-1466.
Lall, S., \& Teubal, M. (1998). Market stimulating' technology policies in developing countries: A framework with examples from East Asia. World Development, 26(8), 1369-1385.

Manchester Trade Team. (2005). Impact of the end of MFA quotas and COMESA's textile and apparel exports under AGOA: Can the Sub-Saharan Africa textile and apparel industry survive and grow in the post-MFA World? Report prepared for USAID East and Central Africa Global Competitiveness Trade $\mathrm{Hub}$.

McCombie, J. S. L. (1986). Verdoorn's law. In J. Eatwell, M. Milgate, \& P. Newman (Eds.), The new palgrave: A dictionary of economics (pp. 261-263). London: Macmillan.

McGreal, C. (2007). Backlash as cheap Chinese labour and products follow investment from Beijing. The Guardian, 5th February.

Mitsuhashi, K. (2006). The furniture value chain from Thailand to Japan: Upgrading and the roles of buyers. D. Phil dissertation, Brighton: University of Sussex.

Morris, M., \& Barnes, J. (2007). Regional development and cluster management: Lessons from South Africa. In J. Allen, Scott, \& Garofoli Gioacchino (Eds.), Development on the ground: Clusters, networks, and regions in emerging Economies. London: Routledge.

Morris, M., Barnes, J., \& Esselaar, J. (2008). Globalisation, the changed global dynamics of the clothing and textile value chains and the impact on Sub Saharan Africa. Vienna: UNIDO.

Morris, M., \& Sedowski, L. (2006a). The competitive dynamics of the clothing industry in Madagascar in the post-MFA environment, PRISM working paper 1, Policy Research in International Services and Manufacturing, SALDRU, University of Cape Town. <www.saldru.uct.ac.za/prism/madagascar_ postmfa.pdf $>$.

Morris, M., \& Sedowski, L. (2006b). Report on government responses to new post-MFA realities in Lesotho', PRISM working paper 2, Policy Research in International Services and Manufacturing, SALDRU, University of Cape Town. <www.saldru. uct.ac.za/prism/lesotho_clothingrept.pdf $>$.

Nelson, R. R. (1993). National innovation systems: A comparative analysis. New York: Oxford University Press.

Ricardo, D. (1817). The principles of political economy and taxation. London: Dent (Reprinted 1973).

Salm, A., Grant, W. J., Green, T. J., Haycock, J. R., \& Raimondo, J. (2002). Lesotho garment industry subsector study for government of Lesotho, Mimeo.

Schmitz, H. (1998). Collective efficiency and increasing returns. Cambridge Journal of Economics, 23(4), 465-483. 
Smith, A. (1776). An enquiry into the nature and cause of The wealth of Nations. 4th ed. (republished in 1976 by Oxford University Press, and edited by R.H. Campbell and A.S. Skinner).

Teece, D., Pisano, G., \& Shuen, A. (1992). Dynamic capabilities and strategic management. Berkeley: University of Berkeley Press.

Tidd, J., Bessant, J., \& Pavitt, K. (2005). Managing innovation: Integrating technological, market and organizational change (3rd ed.). Chichester: John Wiley and Sons Ltd.

UNCTAD. (2003). Handbook on the scheme of The United States Of America. Geneva: UNCTAD.

UNIDO. (2006). International yearbook 2006. Vienna: UNIDO.
USITC. (2004). Textiles and apparel: Assessment of the competitiveness of Certain foreign suppliers to the US Market, Investigation No. 332-448, USITC Publication 3671, Washington, United States International Trade Commission.

World Bank. (2002). Globalization, growth, and poverty: Building an inclusive world economy, Policy Research Report, Washington: World Bank and Oxford: Oxford University Press.

World Bank. (2003). Kenya: A policy agenda to restore growth. Report No. 25840-KE, Washington, DC: The World Bank (<www.worldbank.org/ke/cg2003/ CEM_CG.pdf $>$ ).

WTO (2005). International trade statistics. Geneva: World Trade Organisation.

Available online at www.sciencedirect.com

\section{ScienceDirect}

